\title{
PENGUATAN FUNGSI KEPALA DESA SEBAGAI MEDIATOR \\ PERSELISIHAN MASYARAKAT DI DESA
}

\author{
Sri Lestari Rahayu, Mulyanto, Anti Mayastuti \\ Fakultas Hukum Universitas Sebelas Maret \\ Email : r.srilestari@yahoo.co.id, sheemoel@yahoo.com, \\ antimayastuti@gmail.com
}

\begin{abstract}
.
This study aimed to describe the strength of the functions of the head of the village strengthen the functions of the head of the village to mediate a dispute resolver based on Law Number 6 of 2014 on the village, so it can expand access to justice for rural communities and reduce the caseload of the state judiciary. The law put forward any disputes in rural communities can be resolved by the village head who acts as a mediator to revive the cultural community (gemeinschaaft) and empower local wisdom (local wisdom) in managing disputes, to achieve restorative justice in order to reduce the burden on the state judiciary. The results showed the settlement of disputes through mediation Mojolaban villagers of village heads (non litigation) is more effective than through the court (litigation) for various reasons, among others, cheaper, more efficient, able to maintain good relations and family-oriented as well as characteristics of the community (Gemeinschaft).
\end{abstract}

Keywords : village chief, mediators, local wisdom

\begin{abstract}
Abstrak
Penelitian ini bertujuan untuk mendeskripsikan penguatan terhadap fungsi kepala desa sebagai mediator penyelesai perselisihan berdasar Undang-undang Nomor 6 tahun 2014 tentang Desa, sehingga dapat memperluas access to justice masyarakat pedesaan dan mengurangi beban perkara di peradilan negara. Dalam Undangundang tersebut mengedepankan setiap perselisihan di masyarakat desa dapat diselesaikan oleh kepala desa yang berperan sebagai mediator untuk menghidupkan budaya paguyuban (gemeinschaaft) dan memberdayakan kearifan lokal (local wisdom) dalam mengelola perselisihan, untuk mewujudkan keadilan restoratif guna mengurangi beban peradilan negara. Hasil penelitian menunjukkan penyelesaian sengketa warga Desa Mojolaban melalui mediasi kepala desa (non litigasi) lebih efektif dibandingkan lewat pengadilan (litigasi) dengan berbagai alasan antara lain lebih murah, efisien, dapat menjaga hubungan baik dan bersifat kekeluargaan sebagaimana karakteristik masyarakat paguyuban (Gemeinschaft).
\end{abstract}

Kata Kunci : kepala desa, mediator, kearifan lokal 


\section{A. Pendahuluan}

Sesungguhnya konflik atau perselisihan adalah normal dan tidak dapat dielakkan sepanjang ada interaksi antar manusia. Dalam perspektif antropologi, perselisihan merupakan fenomena sosial yang tidak dapat dipisahkan dari kehidupan manusia, lebih-lebih lagi dalam masyarakat yang bercorak multi budaya. Ia adalah sesuatu yang tidak dapat dihindari dalam kehidupan bersama (James P. Spradley and David W. McCurdy, 1987: 11). Manifest konflik artau perselisihan mempunyai berbagai bentuk misalnya konflik antar pribadi, antar keluarga, antar kelompok dan lain sebagainya.

Secara teknis hukum ada dua pilihan bagi warga masyarakat dalam menyelesaikan perselisihan, yaitu melalui cara judicial (litigasi) oleh peradilan negara dan melalui cara non judicial (non litigasi) oleh pihak ketiga (mediator) (Adi Sulistiyono, 2006: 130-131).

Secara historis dan kultural, masyarakat Indonesia, terutama di pedesaan telah terbiasa menggunakan pranata lokal berbasis kearifan lokal dalam menyelesaiakan perselsihan. Ungkapan seperti menang tanpa ngasorake, ana rembug di rembug, rukun agawe santoso, siro yo ingsun-ingsun yo siro, atau ngalah dhuwur wekasane dan sebagainya, adalah nilai-nilai kearifan lokal dalam menyelesaikan perselisihan di masyarakat pedesaan Jawa pada umumnya. Demikian juga, ungkapan lokal yang mengedepankan harmoni, kedamaian, dan persaudaraan dalam penyelesaian perselsihan seperti segilikseguluk salunglung sabayantaka, paras paros sarpanaya, menyama braya di Bali (I Putu Gelgel, 2011).

Pendayagunaan kearifan lokal sebagai resolusi konflik dapat dilakukan melalui implementasi teknis penyelesaian perselisihan bahkan kekerasan. Secara kultural di sebagain besar tatanan lokal yang hidup di nusantara telah berkembang praktek teknis resolusi konflik (Ade Saptomo, 2010: 95-109). Dalam menata, memperbaiki, dan menjaga harmoni di Desa Pakraman di Bali dilakukan dengan mengedepankan penyelesaian konflik melalui perundingan diantara mereka yang berselisih secara damai dan kekeluargaan. Jika perselisihan tidak dapat diselesaikan melalui perundingan di antara mereka, 
maka di tempuh pola mediasi yaitu penyelesaian sengketa yang dimediatori oleh Majelis Desa Pakraman sebagai suatu bentuk peradilan adat.

Penyelesaian konflik secara damai sangat penting dikedepankan untuk mempertahankan harmoni sosial dalam kehidupan masyarakat, serta tidak menimbulkan luka batin yang menyisakan dendam berkepanjangan. Penyelesaian secara damai dan kekeluargaan ini, intinya adalah permohonan maaf dari pihak yang melakukan kesalahan kepada pihak yang dirugikan dan pihak yang dirugikan bersedia menerima permohonan maaf serta bersedia pula untuk memaafkan pihak yang melakukan kesalahan. Masyarakat di Bali lebih percaya dengan putusan lembaga peradilan adatnya. Ada rasa keadilan yang sebenarnya tercermin dari tiap putusan hukum adatnya (Made Sudjana, 2010). Di Bengkulu, pada klan Selupu Lebong, dikenal pengadilan yang melibatkan pelindung adat, ketua kutai dan ketua suku/klan (Abdul Kholik, 2010, http ://blog.unsri.ac.id/revolusi-jalanan/artikel-sosial-budaya/diakses 28 Juli 2010). Di Takalar, Sulawesi Selatan dikenal Imam Desa yang kurang lebih menjalankan fungsi yang sama yaitu sebagai mediator dalam konflik lokal (Jawahir Tontowi, 2007: 72).

Peran seorang kepala desa menjadi sangat penting dalam penyelesaian perselisihan di masyarakat desa. Secara historis pada masa Hindia Belanda telah dikenal adanya peradilan desa. Melalui Stb. 1935, tahun 1935, Nomor 102 disisipkan Pasal 3 a ke dalam Rechterlijke Organisatie (RO) yang secara singkat menyebutkan tetap mengakui kewenangan hakim-hakim dari masyarakat hukum kecil-kecil (desa) untuk memeriksa perkara-perkara adat yang menjadi kewenangannya, untuk mengadili secara adat tanpa menjatuhkan hukuman (pidana) (Mahadi, 1991: 36). Kewenangan hakim-hakim ini tidak mengurangi kewenangan para pihak untuk setiap saat menyerahkan perkaranya kepada putusan hakim. Dengan disisipkannya pasal ini, kemudian diakui kedudukan peradilan desa (Soerjono Soekanto, 1986: 42-44). Dalam kenyataannya, selama pemerintahan kolonial Belanda dikenal dua bentuk peradilan bagi orang pribumi, yaitu peradilan adat dan peradilan desa (Tim HuMa, 2003: 3) 
Sejalan dengan ketentuan dalam Undang-Undang Nomor 6 Tahun 2014 tentang Desa yang menegaskan fungsi kepala desa sebagai penyelesai perselisihan. Pasal 26 (1) menyebutkan : "Kepala Desa bertugas menyelenggarakan Pemerintahan Desa, melaksanakan Pembangunan Desa, pembinaan kemasyarakatan Desa, dan pemberdayaan masyarakat Desa”. Selanjutnya Pasal 26 (4) huruf k. menyatakan : Dalam melaksanakan tugas sebagaimana dimaksud pada ayat (1), Kepala Desa berkewajiban : menyelesaikan perselisihan masyarakat di Desa;"

Dalam rangka menekankan fungsi kepala desa sebagai penyelesai perselisihan, Pasal 28 mengancam melalui sanksi, sebagaimana ditegaskan :

(1) Kepala Desa yang tidak melaksanakan kewajiban sebagaimana dimaksud dalam Pasal 26 ayat (4) dan Pasal 27 dikenai sanksi administratif berupa teguran lisan dan/atau teguran tertulis.

(2) Dalam hal sanksi administratif sebagaimana dimaksud pada ayat (1) tidak dilaksanakan, dilakukan tindakan pemberhentian sementara dan dapat dilanjutkan dengan pemberhentian.

Ketentuan Undang-Undang Nomor 6 Tahun 2014 tentang Desa maupun dalam Peraturan Pemerintah Nomor 43 Tahun 2014 tentang Peraturan Pelaksanaan Undang-Undang Nomor 6 Tahun 2014 tentang Desa, sama sekali tidak menjelaskan tentang jenis perkara/perselisihan, mekanisme, bentuk, produk putusan maupun implikasi hukum dari penyelesaian perselisihan kepaka desa.

Tidak jelas apakah kepala desa bertindak sebagai "hakim desa" atau sebagai mediator seperti dalam alternatif dispute resolution (ADR). Hal ini berbeda dengan Desa Adat sebagaimana diatur pada Bagian Kedua, Kewenangan Desa Adat, Pasal 103 : "Kewenangan Desa Adat berdasarkan hak asal usul sebagaimana dimaksud dalam Pasal 19 huruf a meliputi:

a. pengaturan dan pelaksanaan pemerintahan berdasarkan susunan asli;

b. pengaturan dan pengurusan ulayat atau wilayah adat;

c. pelestarian nilai sosial budaya Desa Adat; 
d. penyelesaian sengketa adat berdasarkan hukum adat yang berlaku di Desa Adat dalam wilayah yang selaras dengan prinsip hak asasi manusia dengan mengutamakan penyelesaian secara musyawarah;

e. penyelenggaraan sidang perdamaian peradilan Desa Adat sesuai dengan ketentuan peraturan perundang-undangan;

Fungsi kepala desa sebagai penyelesai perselisihan sangat strategis dalam mendukung bekerjanya peradilan negara di Indonesia, apalagi ipso facto negara ini tengah mengalami perubahan dan pergeseran dari gemeinschaft (paguyuban) ke gesselschaft (patembayan). Dalam rangka memperkuat nilainilai paguyuban maka fungsi kepala desa sebagai penyelesai perselisihan berbasis kearifan lokal yang telah dipertegas oleh Undang-Undang Nomor 6 Tahun 2014 tentang Desa harus didayagunakan semaksimal mungkin sebagai ihktiar untuk memperluas akses keadilan bagi warga masyarakat.

\section{B. Metode Penelitian}

Penelitian ini menggunakan paradigma legal constructivism (Soetandyo Wignjosoebroto, 2002: 103), yang melihat realitas itu ada dalam bentuk bermacam-macam konstruksi mental, berdasarkan pengalaman sosial, bersifat lokal dan spesifik dan tergantung pada orang yang melakukannya. Oleh karena itu metode utama yang digunakan adalah hermeneutic dan dialectics (Soetandyo Wignjosoebroto, 2002: 97). Sejalan dengan paradigma penelitian yang digunakan maka pendekatan penelitian yang digunakan berupa penelitian empiris. Di samping itu, penelitian dilengkapi dengan kajian normatif menggunakan pendekatan perundang-undangan (statute approach) terhadap bahan-bahan hukum yang relevan. Penelitian dilaksanakan di Provinsi Bali (Kabupaten Tabanan) dan Provinsi Jawa Tengah (Kabupaten Sukoharjo). Sumber data primer diperoleh melalui wawancara di lapangan dengan narasumber yang terpilih (purposive sampling). 


\section{Pembahasan}

\section{Fungsi Kepala Desa Sebagai Penyelesai (Mediator) Perselisihan Perselisihan Masyarakat Di Desa}

Peselisihan atau sengketa yang melibatkan dinamika sosial budaya ini haruslah dikelola dengan baik agar terhindar dari konflik yang lebih besar dan meluas. Oleh karena itu diperlukan suatu mekanisme yang tepat untuk menyelesaikan sengketa antar warga ini. Juga perlu adanya antisipasi sengketa yang akan bermuara kepada konflik komunal masyarakat. Salah satu metode yang memberikan solusi kemenangan bagi pihak yang bertikai adalah melalui mekanisme mediasi. Salah satu pihak yang memiliki potensi dan peluang besar utuk menjadi mediator adalah pemimpin wilayah misalnya kepala desa, yang mengerti betul akan kondisi warganya dan tentunya dihormati oleh warganya (http://satriagovernmentunhas09.blogspot.com/2012/06/peran-pemimpin kepala-desa-sebagai.html).

Undang-Undang Nomor 6 Tahun 2014 tentang Desa menggunakan istilah "perselisihan", untuk menyebut konflik atau sengketa yang terjadi dilingkungan masyarakat desa. Sekalipun demikian tampaknya oleh pembuat undang-undang yang dimaksud dengan perselisihan itu tidak berbeda dengan konflik atau sengketa. Istilah konflik ini secara etimologis berasal dari bahasa Latin "con" yang berarti bersama, dan "fligere" yang berarti benturan atau tabrakan. Secara sosiologis, konflik diartikan sebagai suatu proses sosial antara dua orang atau lebih (bisa juga kelompok) dimana salah satu pihak berusaha menyingkirkan pihak lain dengan menghancurkannya atau membuatnya tidak berdaya.

Dengan demikian konflik dalam kehidupan sosial berarti terjadinya benturan kepentingan, pendapat, harapan yang harus diwujudkan dan sebagainya yang paling tidak melibatkan dua pihak atau lebih, dimana tiap-tiap pihak dapat berupa perorangan, keluarga, kelompok kekerabatan, satu komunitas, maupun satu organisasi sosial pendukung ideologi tertentu, satu organisasi politik, suku bangsa maupun satu pemeluk agama tertentu. 
Namun patut didugaa bahwa pengetahuan mengenai atenative dispute resolution (ADR) sendiri belum terlalu dipahami oleh para kepala desa. Kurangnya pemahaman kepala desa dalam melaksanakan peran sebagai pemimpin sekaligus dapat menjadi mediator dalam penyelesaian perkara antar warga masyarakatnya, mengakibatkan tidak berhasilnya proses mediasi atau bahkan banyak warga yang memiliki sengketa/perselisihan tidak banyak memanfaatkannya.

Dalam pengertian sosiologis, perselisihan, sengketa atau konflik (dispute) dapat difahami sebagai suatu "proses sosial" di mana dua orang atau dua kelompok orang berusaha menyingkirkan pihak lain dengan cara menghancurkan atau membuatnya tidakberdaya (Bambang Sugeng, 2011: 1).

Perselisihan merupakan suatu proses yang bersifat disosiatif. Salah satu penyebab konflik yakni pendirian dan keyakinan. Apabila kekuatan masingmasing pihak yang berkonflik berimbang maka kemungkinan besar akan terjadi usaha akomodasi. Sebaliknya apabila kekuatan yang tengah berselisih tidak berimbang, maka akan terjadi penguasaan (dominasi) pihak yang kuat terhadap lawannya (J. Dwi Narwoko dan Bagong Suyanto, 2007: 70).

Proses penyelesaian perselisihan (disputes processed) yang dilakukan melalui jalur non judicial dapat dikelompokkan dalam berbagai bentuk mekanisme, yaitu penyelesaian melalui pranata-pranata lokal tradisional dan cara-cara non formal lainnya di luar pengadilan yang dikenal dengan Alternatif Dispute Resolution (ADR) (Idrus Abdullah, 2002: 1). Menurut Barda Nawawi Arief Barda (Nawawi Arief, 2008, www.bardanawawi.file.wordpress.com. diakses tanggal 26 Oktober 2010) bahwa mediasi penal merupakan salah satu bentuk alternatif penyelesaian sengketa di luar pengadilan (yang biasa dikenal dengan istilah ADR atau "Alternatif Dispute Resolution", ada pula yang menyebutnya "Apropriate Dispute Resolution" ADR pada umumnya digunakan di lingkungan kasus-kasus perdata, tidak untuk kasus-kasus pidana, hal ini bias dilihat di Undang-Undang Nomor 30 tahun 1999 tentang Arbitrase dan Alternatif Penyelesaian Sengketa. Berdasarkan perundang-undangan yang berlaku di Indonesia saat ini (hukum positif) pada prinsipnya kasus pidana 
tidak dapat diselesaikan di luar pengadilan, walaupun dalam hal-hal tertentu, dimungkinkan adanya penyelesaian kasus pidana di luar pengadilan.

Bentuk penyelesaian konflik yang lazim dipakai, yakni : (a) konsiliasi (perdamaian) yaitu suatu cara untuk mempertemukan pihak-pihak yang berselisih guna mencapai persetujuan bersama untuk berdamai; (b) Mediasi, yaitu suatu cara menyelesaikan pertikaian dengan menggunakan seorang pengantara (mediator); (c) Arbitrasi, artinya melalui pengadilan, dengan seorang hakim (arbiter) sebagai pengambil keputusan; dan (d) Koersi, ialah suatu cara menyelesaikan pertikaian dengan menggunakan paksaan fisik atau pun psikologis (Bambang Sugeng, 2011: 4-5).

Fungsi Kepala Desa dalam melaksanakan kewajiban menyelesaikan perselisihan masyarakat di desa sebagaimana yang dimaksud Pasal 26 (4) huruf k. Undang-Undang Nomor 6 Tahun 2014 tentang Desa yang menyatakan : Dalam melaksanakan tugas sebagaimana dimaksud pada ayat (1), Kepala Desa berkewajiban : menyelesaikan perselisihan masyarakat di Desa menurut hemat peneliti tidak lain adalah fungsi kepala desa untuk berperan sebagai mediator.

Secara etimologi, istilah mediasi berasal dari bahasa Latin, mediare yang berarti berada di tengah. Makna ini menunjuk pada peran yang ditampilkan pihak ketiga sebagai mediator dalam menjalankan tugasnya menengahi dan menyelesaikan sengketa antara para pihak. "Berada di tengah" juga bermakna mediator harus berada pada posisi netral dan tidak memihak dalam menyelesaikan sengketa. Ia harus mampu menjaga kepentingan para pihak yang bersengketa secara adil dan sama, sehingga menumbuhkan kepercayaan (trust) dari para pihak yang bersengketa.

Mediasi sebagai salah satu alternatif penyelesaian sengketa juga telah dikenal luas dan banyak digunakan berbagai pihak dalam menyelesaikan sengketa di luar pengadilan. Mediasi adalah intervensi terhadap suatu sengketa atau negosiasi oleh pihak ketiga yang dapat diterima, tidak berpihak dan netral yang tidak mempunyai kewenangan untuk mengambil keputusan dalam membantu para pihak yang berselisih dalam upaya mencapai kesepakatan 
secara sukarela dalam penyelesaian permasalahan yang disengketakan (Christopher W Moore, 1986). Mediation in negotiation carried out with the assistance of a third party (Stephen B. Goldberg, dkk, 1992: 103). Dalam Undang-Undang Nomor 30 Tahun 1999, alternatif penyelesaian sengketa adalah lembaga penyelesaian sengketa atau beda pendapat melalui prosedur yang disepakati para pihak, yakni penyelesaian di luar pengadilan dengan cara konsultasi, negosiasi, mediasi, konsiliasi, atau penilaian ahli."

Secara umum mediasi dapat diartikan upaya penyelesaian sengketa para pihak dengan kesepakatan bersama melalui mediator yang bersikap netral, dan tidak membuat keputusan atau kesimpulan bagi para pihak tetapi menunjang fasilitator untuk terlaksananya dialog antar pihak dengan suasana keterbukaan, kejujuran dan tukar pendapat untuk tercapainya mufakat. Dengan kata lain, proses negosiasi pemecahan masalah dimana pihak luar yang tidak memihak (impartial) dan netral bekerja dengan pihak yang bersengketa untuk membantu mereka memperoleh kesepakatan perjanjian dengan memuaskan (win-win solution).

Kepala desa adalah tokoh yang dapat memainkan peran penting sebagai mediator dalam penyelesaian perselisihan dalam masyarakatnya. Hal ini tidak lepas dari posisi kepala desa yang pada umumnya merupakan tokoh yang disegani oleh lingkungan masyarakatnya, di samping menurut Undang-Undang Nomor 6 Tahun 2014 tentang Desa menyatakan bahwa kepala desa adalah pemimpin pemerintahan yang memiliki posisi yang kuat (berwibawa) sehingga diharapkan akan efektif dalam menjalankan peran sebagai seorang mediator atau penyelesai perselisihan.

Pada umumnya dikenal tiga tipe mediator sebagaimana dikemukakan oleh Joseph Spence. They are the social network type, the authoritative type, and the independent type mediators (Joseph Spence, Sr. 2010, http://EzineArticles.com/5133589). Pertama, social network mediators, yaitu mediator yang berperan dalam suatu penyelesaian sengketa atas dasar adanya hubungan sosial dengan para pihak yang bersengketa; Kedua, authoritative mediators, yaitu mediator yang berusaha membantu pihak-pihak yang 
bersengketa untuk menyelesaikan konflik dan memiliki posisi yang kuat (berwibawa), sehingga memiliki kapasitas untuk mempengaruhi hasil akhir proses mediasi. Ketiga, independent mediators, yaitu mediator yang menjaga jarak antar-pribadi maupun dengan persoalan yang tengah dihadapi.

Fungsi kepala desa sebagai penyelesai perselisihan pada dasarnya merupakan mediasi yang memiliki bentuk antara social network mediators dan authoritative mediators. Secara historis fungsi tersebut sejak dahulu dikenal sebagai hakim peradilan desa atau dorpjustitie (Nader L. dan HF. Todd (ed.), 1978: 10). Fungsi kepala desa sebagai penyelesai perselisihan sebagaimana diatur dalam Pasal 26 (4) huruf k Undang-Undang Nomor 6 Tahun 2014 tentang Desa tidak terlepas dari kenyataan historis bahwa di masa lalu di tingkat desa dan masyarakat hukum adat dikenal adanya peradilan desa dan atau peradilan adat.

Sekalipun Pasal 6 ayat (1) PERMA Nomor 01 Tahun 2008 menyatakan Hakim Pengadilan Negeri-lah yang dapat menjadi seorang mediator sedangkan pihak lain, yakni orang yang ditentukan sendiri oleh para pihak untuk bertindak sebagai mediator tapi harus terlebih dahulu memiliki sertifikat sebagai mediator, hal tersebut tidak berlaku jika proses mediasi terjadi di luar pengadilan sebagaimana yang dilakukan oleh kepala desa. Kepala desa melaksanakan tugas sebagai penyelesaian perselisihan merupakan kewenangan yang bersumber dari atribusi berdasar Undangundang Nomor 6 Tahun 2014 tentang Desa. Konsekuensinya adalah seorang kepala desa tidak harus memiliki sertifikasi mediator untuk dapat melaskanakan tugas sebagai penyelesai perselisihan.

Secara empiris di banyak masyarakat hukum adat lainnya keberadaan peradilan adat ipso facto masih sangat berperan besar sebagai self regulating mechanism atau sering disebut sebagai community justice system (Kurnia Warman, 2003: 90) yang bekerja secara informal namun otonom. Lembaga ini melalui mekanisme-mekanisme yang dimiliki berfungsi sebagai penyelesai, dan/atau sebagai pemulih situasi tertib pada umumnya (Soetandyo Wignjosoebroto, 1994: 136). 
Sementara itu di luar peradilan adat yang dikenal dalam kesatuan masyarakat hukum adat (terutama yang terdapat pada desa-desa di Jawa) dikenal adanya peradilan desa yang dijalankan hakim perdamaian desa untuk menyelesaikan perkara-perkara tertentu. Perkara yang dapat ditangani oleh hakim perdamaian desa pada umumnya adalah perkara perdata, pidana ringan serta pelanggaran-pelanggaran tatanan/norma-norma hukum adat dimana kepala desa mendamaikan dan menyelesaikan perkara menurut asas-asas dan sistem adat / hukum adat serta kesadaran hukum masyarakat.

Dalam konteks Indonesia peradilan desa dan atau peradilan adat merupakan "peradilan non-negara" atau "peradilan informal" yang hakikatnya adalah "penyelesaian sengketa di-tingkat lokal" - yang dilakukan oleh kepala desa, para pemuka adat, tokoh masyarakat, dan tokoh agama - kadang-kadang didasarkan pada tradisi, namun sering pula hanya berdasarkan pertimbangan subyektif para pemimpin warga tanpa dasar yang jelas atau mengacu kepada hukum negara maupun hukum adat (Bank Dunia, 2009: vii).

Menurut catatan Bank Dunia, fungsi kepala desa sebagai penyelesai perselisihan setidak memiliki beberapa kelebihan (Bank Dunia, 2009: ix).

a. Pertama, untuk sebagian besar kasus kecil dan ringan, peradilan informal merupakan proses yang tepat dan efektif.

b. Kedua, hakim perdamaian desa memiliki legitimasi dan otoritas lokal, yang tidak selalu dimiliki peradilan negara.

c. Ketiga, prosedur dan substansinya sesuai dengan pendapat umum yang mengutamakan kerukunan.

d. Keempat, tujuannya bersifat menghindari konfl ik dan bersifat restoratif; dan prosesnya bersifat cepat dan sangat murah.

e. Kelima, efektif dan efisien bagi masyarakat pedesaan yang saling bergantung satu sama lain secara ekonomi dan sosial.

f. Keenam, 69 (enampuluh) persen responden menyatakan kepuasannya pada hakim perdamaian desa dibandingkan dengan 58 (lima puluh delapan) persen responden puas dengan pelaku peradilan formal. 
Kelebihan yang dimilki fungsi kepala desa sebagai penyelesai perselisihan yang demikian itu akan sangat signifikan dalam mengurangi arus masuknya perkara ke peradilan negara yang sekarang sudah overloaded. Banyak sengketa perdata dan perkara pidana adat, kasus "sandal jepit", atau delik aduan akan lebih efektifdan efisien diselesaikan oleh peradilan informal (peradilan adat) yang diharapkan dapat memberikan restorative justice (Musakkir, 2011).

Sebagai perbandingan, dibeberapa negara fungsi kepala desa sebagai penyelesai perselisihan telah diperkuat melalui politik hukum yang mengakui (recognition) dan instrumen perundang-undang negara. Pemerintah Papua Nugini mendirikan sebuah Unit Perantara Peradilan Komunitas (Community Justice Liaison Unit atau CJLU) sebagai bagian resmi bidang pemerintahan di Sektor Hukum dan Peradilan, dengan tujuan meningkatkan kesesuaian dan konsistensi antara sistem formal dan informal dan meningkatkan kapasitas pelaku peradilan di luar negara (Pat Howley, 2007: 1). Di Samoa barat, kepala desa atau Fono memiliki tanggungjawab untuk merumuskan hukum yang berlaku di masyarakat, menyelesaikan sengketa melalui musyawarah adat dan memutuskan bentuk sanksi yang harus dilaksanakan (Gabriel Maxwell and $\mathrm{H}$. Hayes, 2006: 144-145). Hingga saat ini lembaga Fono tetap eksis di Samoa Barat dan di akui dalam sebuah undang-undang yang disebut Village Fono Act, Tahun 1990.

Di Filipina, Sistem Peradilan Barangay atau The Barangay Justice System (BJS) merupakan program konsiliasi dan mediasi wajib di tingkat barangay, komunitas adat atau desa, dilaksanakan di 42.000 barangay (Bank Dunia, 2009, 54). Perundang-undangan Pilipina membatasi kewenangan Katarungang Pambaranay sebagai peradilan adat hanya untuk untuk menangani kasus-kasus pidana ringan (Alfredo Tadiar, 1998: 24).

Di Bangladesh, keberadaan kepala desa dalam lembaga Shalish sangat efektif dalam menyelesaian sengketa di masyarakat, maka sejumlah upaya pembaharuan lembaga ini pun dilakukan oleh berbagai pihak antara lain oleh Madaripur Legal Aid Asociation (MLAA) (Eva Achjani Zulfa, 2010: 193-194). 


\section{Efektivitas Penyelesaian Perselisihan oleh Kepala Desa Di Kecamatan}

Mojolaban Kabupaten Sukoharjo

Mekanisme penyelesaian perselisihan warga masyarakat desa dapat dideskripsikan berdasarkan hasil kuesioner yang telah diedarkan ke 15 (lima belas) desa di kecamatan Mojolaban, Sukoharjo yakni yakni Desa Laban, Desa Klumprit, Desa Laban, Desa Sapen, Desa Plumbon, Desa Tegalmade, Desa Demakan, Desa Palur, Desa Kragilan, Desa Bekonang, Desa Wirun, Desa Triyagan, Desa Gadingan, Desa Dukuh dan Desa Cangkol. Hasil penelitian menunjukkan bahwa pada umumnya sengketa yang terjadi di desa masalah warisan, pertanahan, konflik keluarga, pekat, perceraian, Perselingkuhan, Swadaya pembangunan infrastruktur dan sebagainya. Secara lebih jelas dapat digambarkan dalam bagan berikut.

\section{Bagan 1. Pembidangan Sengketa Warga Desa Di Mojolaban}

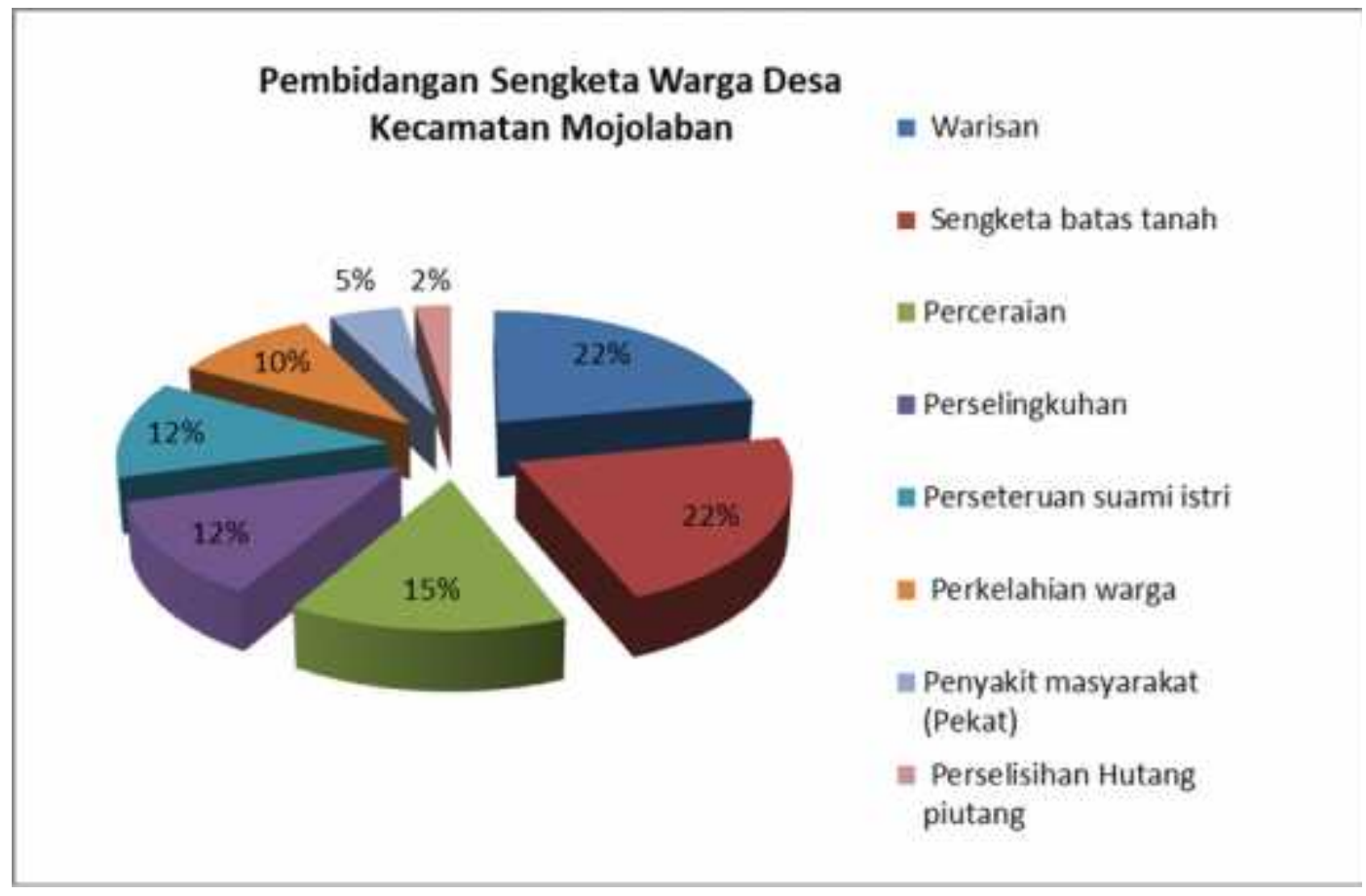

Dari diagram tersebut di atas dapat diketahui dapat dideskripsikan sebagai berikut. Pertama, ada berbagai variasi pembidangan sengketa masyarakat desa yang didominasi masalah warisan (22\%) dan sengketa batas tanah (22 \%) disusul sengekata masalah perceraian sebanyak $15 \%$. Kasus perselingkuhan dan perseteruan suami istri sama-sama sebanyak $12 \%$, selanjutnya perkelahian 
warga sebesar $10 \%$, sengketa penyakit masyarakat sebanyak $5 \%$ dan terakhir perselisihan hutang-piutang sebesar $2 \%$. Artinya ada berbagai masalah pribadi warga desa dapat menjadi sengketa yang memerlukan bantuan penyelesaian melalui kepala desa. Jika dilihat lebih mendapat berbagai maslahat tersebut dapat dikategorikan sebagai masalah perdata maupun pidana namun dalam kenyataan di dalam masyarakat tidak membedakan maslah tersebut yang penting dengan meminta bantuan kepala desa selaku mediator dapat menyelesaiakn permasalahannya.

Kedua, Temuan di lapangan bahwa berdasarkan hasil wawancara dengan Kepala Desa Dukuh, Kecmatan Mojolaban, Kabupaten Sukoharjo yakni Bapak Marsudi yang telah menjabat selama 2,8 tahun diperoleh informasi bahwa beliau sering menjadi mediator perselisihan warganya dalam masalah perkelahian warga, perceraian dan sengketa warisan. Sebagai catatan menarik bahwa satu masalah yang belum terselesaikan adalah sengketa tanah warisan dari Kades pertama sampai sekarang, tidak bisa selesai, kalau mau jelas saya sowan, atau Dinas terkait rawuh di Desa kami, Desa Dukuh Kecamatan Mojolaban.

Ketiga, Ada hal menarik lainnya, bahwa semua sample kepala desa pernah menjalankan tugas sebagai mediator bahkan sering. Artinya 100\% Kepala Desa pernah menjalankan fungsi mediasi bagi warga masyarakat desa di Kecamatan Mojolaban. Bahkan dari sampel penelitian 40\% Kepala Desa menyatakan sering menjadi penyelesai (mediator) bagi warga masyarakat desa. Sisanya 60 $\%$ pernah menjadi mediator sengketa warga masyarakat desa. Artinya sengketa yang terjadi masyakarakat sebenarnya sangat potensial meluas, sehingga dibutuhkan kesadaran masyarakat desa dan kepala desa untuk menyelesaiakan masalah secara damai melalui pemimpin desa dalam hal ini kepala desa sebagai authoritative mediator.

Adapun untuk mekanisme mediasi yang dilakukan tiap-tiap kepala desa dalam mendamaikan perselisihan warga desa tergantung dari gaya kepemimpinan masing-masing desa. Namun, dapat dicatat pada dasarnya semua kepala desa lebih mengedepankan win-win solution. Mekanisme mediasi 
kepala desa dengan mengundang pihak-pihak yang berselisih ke Balai Desa untuk diadakan musyawarah. Melakukan Pendekatan persuasif dan dipertemukan kedua belah pihak untuk mencari solusi terbaik supaya tidak timbul masalah lagi, menghasilkan keputusan yang baik untuk semuanya. Teknisnya dengan mengumpulkan keterangan dari masing-masing pihak kemudian menyampaikan berbagai alternatif penyelesaian yang dipilih oleh masing-masing pihak sehingga maslah yang dihadapi dapat diselesaikan secara tuntas tanpa ada yang merasa menang dan kalah dengan pendekatan win-win solution.

Dari segi kultural, masyarakat Indonesia, terutama di pedesaan telah terbiasa menggunakan pranata lokal berbasis local wisdom dalam menyelesaikan perselisihan. Nilai-nilai local wisdom masyarakat jawa merupakan acuan masyarakat yang meliputi seluruh aspek kehidupan yang salah satunya berupa kata-kata bijak maupun pepatah. Ketika harus menyelesaikan sengketa warga desa disemangati dengan pesan, "Rukun agawe sentosa, padu agawe bubrah". Ada pepatah, "Menang tanpa ngasorake" (Menang tanpa harus merendahkan) Menghargai dan menjaga jangan sampai melukai batin orang lain lebih diutamakan. Karena tidak seorangpun suka direndahkan.

Di kalangan masyarakat Jawa, yang majemuk dan dinamis, kearifan lokal berupa pesan-pesan bijak, seperti Rawe-rawe rantas malang-malang putung dan Holopis kontol baris; dijadikan semboyan dan penyemangat kebersamaan dalam berjuang melawan penjajah (dulu), dan ketidakadilan (sekarang). Ketika dilaksanakan pembangunan daerah untuk kesejahteraan rakyatnya, dimunculkanlah semboyan "Gotong Royong dan Jer basuki mowo beyo." Ketika harus menyelesaikan pertikaian dan konflik, disemangati dengan pesan"Rukun agawe sentosa, padu agawe bubrah, serta Musawarah lan mupakat”, dan seterusnya, hasilnya positif.

Selanjutnya untuk pola atau model penyelesaian sengketa warga desa di Kecamatan Mojolaban Sukoharjo, dapat dicermati pada diagram berikut : 


\section{Bagan 2. Diagram Model Penyelesaian Warga Desa Mojolaban}

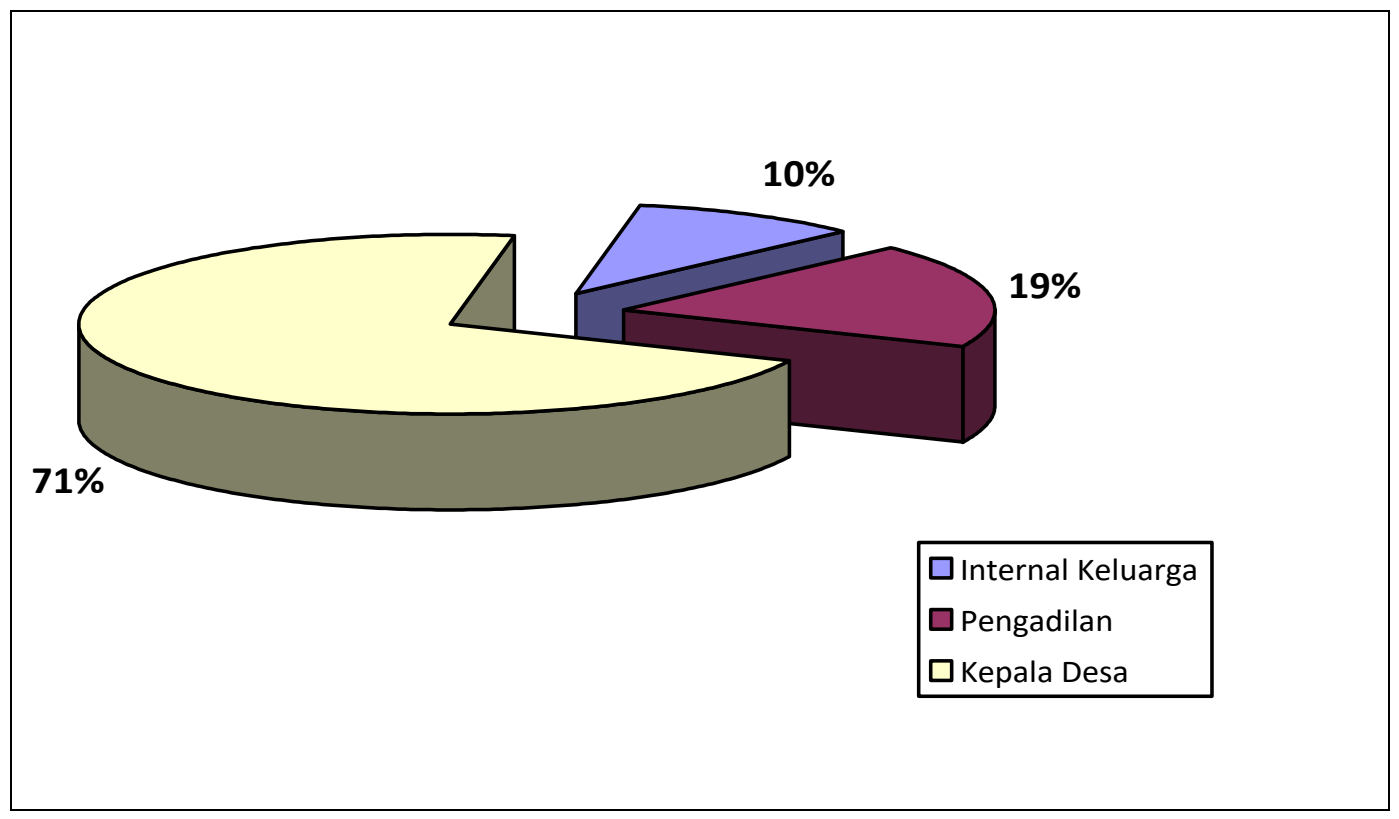

Dari diagram tersebut di atas dapat diketahui bahwa pola atau model penyelesaian warga Desa Mojolaban dapat dideskripsikan sebagai berikut : Model penyelesaian warga desa dalam menghadapi sengketa akan diselesaikan secara kekeluargaan dengan melibatkan internal keluarga sendiri sebanyak 10 $\%$, sedangkan model penyelesaian mengunakan jalur pengadilan (litigasi) lebih banyak yakni $19 \%$, sedangkan mayoritas warga dalam menyelesakan masalah yang dihadapi melalui bantuan mediasi kepala desa sebanyak $71 \%$. Artinya bahwa kepala desa selaku pemimpin di level desa menjadi tumpuan utama bagai warga masyarakat desa dalam menyelesaikan masalahnya masingmasing. Hal sesuai karakteristik masyarakat desa yang bersifat paguyuban berbeda halnya dengan diperkotaan yang memiliki karakteristik patembayan.

Terkait derajat efektivitas penyelesaian sengeketa oleh kepala desa, berdasarkan kuesioner dapat dideskripskan sebagai berikut. Pertama, semua responden sebanyak $100 \%$ menjawab lebih efektif penyelesaian lewat jalur 
kepala desa jika dibandingkan dengan jalur pengadilan dengan berbagai alasan sebagai berikut:

a. Kepala desa, karena lebih murah dan memuaskan kedua pihak. (Desa Tegal Made)

b. Kepala Desa, karena lebih memilih orang yang dipasrahkan RT, RW, Kadus sampai Kepala Desa (Desa Palur)

c. Diselesaikan Kepala Desa bersama dengan tokoh yang ada, melibatkan Babin Kamtibmas dan Babinsa, supaya tidak ada dendam dan kedepan hubungan tetap baik, kondusif, dan harmonis (Desa Demakan)

d. Memilih Kepala Desa, sebab lebih efisien dan murah biaya. (Desa Sapen).

e. Kepala Desa dengan alasan hubungan pihak yang berselisih tetap terjaga dan dari aspek keuangan biaya lebih ringan (Desa Kragilan).

f. Kebanyakan banyak perselisihan warga yang diselesaikan di tingkat desa jadi tidak perlu ke tingkat pengadilan/polisi. (Desa Bekonang)

g. Kepala Desa dulu, jika tidak bisa dimediasi oleh Kepala Desa baru ke pengadilan. (Desa Cangkol)

h. Kalau bisa diselesaikan di tingkat desa, diselesaikan Kepala Desa. (Desa Klumprit)

i. Efektif melalui Kepala Desa karena mediasi bersifat kekeluargaan, murah biaya dengan menjalin komunikasi tetap baik. (Desa Wirun).

j. Relatif tergantung tingkat perkaranya/perselesihan pada umumnya masih banyak yang memilih penyelesaian ke Kepala Desa, hanya orang-orang yang ada gengsi/harga diri memilih ke Pengadilan. (Desa Triyagan)

k. Untuk permasalahan non pidana banyak terselesaikan dimediasi desa (RT/RW maupun Pemdes/Kades). (Desa Laban)

1. Perkara-perkara yang ada sama dan penyelesaiannya bisa selesai di desa, kecuali kasus perjudian dan masalah narkoba. (Desa Dukuh)

m. Tergantung permasalahan dan pribadi orangnya, kebanyakan cenderung minta difasilitasi Kepala Desa. (Desa Gadingan)

n. Dimungkinkan diselesaikan di tingkat desa lebih efektif dan efisien. (Desa Joho). 
o. Ke Kepala Desa dekat, mudah, ditemui dan bersifat musyawarah mufakat untuk meruju kesepakatan, cepat dan biaya murah serta tetap berhubungan baik yang perselisihan tersebut. Sangat efektif bila ada perselisihan warga masyarakat desa diselesaikan oleh Kepala Desa untuk musyawarah mufakat. (Desa Plumbon);

Artinya jawaban mutlak lebih memilih mekanisme mediasi kepala desa dibandingkan lewat pengadilan. Hal tersebut sesuai dengan teori kelebihan mediasi non litigasi yakni (1) Biaya murah dan penyelesaian cepat; (2) Hasil memuaskan bagi para pihak; (3) Kesepakatan komprehensif (prosedural maupun psikologis); (4) Memperbaiki komunikasi antara para pihak yang bersengketa; (5) Memelihara hubungan yang sudah berjalan, atau mengakhiri dengan cara lebih bersahabat; (6) Membantu melepaskan kemarahan dan meningkatkan kesadaran akan kekuatan dan kelemahan posisi masing-masing pihak; (7) Keputusan lebih mudah dilaksanakan dan (8) Kesepakatan lebih baik dari prosedur menang kalah.

\section{Simpulan}

1. Fungsi kepala desa sebagai penyelesai (mediator) perselisihan masyarakat di desa telah diatur secara eksplisit dalam Pasal 26 ayat (1) dan ayat (4) Undang-Undang Nomor 6 Tahun 2014 tentang Desa. Bahkan untuk lebih menekankan fungsi kepala desa sebagai penyelesaian perselisihan, Pasal 28 mengancam melalui sanksi, bagi Kepala Desa yang tidak melaksanakan kewajiban tersebut dikenai sanksi administratif berupa teguran lisan dan/atau teguran tertulis. Dalam hal sanksi administratif tidak dilaksanakan, maka dilakukan tindakan pemberhentian sementara dan dapat dilanjutkan dengan pemberhentian.

2. Berdasarkan data yang disajikan, dari penyebaran kuesioner melalui 15 (lima belas) Kepala Desa di Kecamatan Mojolaban diperoleh hasil bahwa model penyelesaian perselisihan warga desa diselesaikan secara internal kekeluargaan dengan melibatkan internal keluarga sebanyak $10 \%$, menggunakan jalur pengadilan (litigasi) lebih banyak 19\%, sedangkan mayoritas warga memilih mediasi kepala desa sebanyak 71\%. Hasil 
penelitian menunjukkan penyelesaian sengketa warga Desa Mojolaban melalui mediasi kepala desa (non litigasi) lebih efektif dibandingkan lewat pengadilan (litigasi) dengan berbagai alasan antara lain lebih murah, efisien, dapat menjaga hubungan baik dan bersifat kekeluargaan sebagaimana karakteristik masyarakat paguyuban (Gemeinschaft).

\section{E. Saran}

Fungsi kepala desa dalam melaksanakan kewajiban menyelesaikan perselisihan masyarakat di desa berdasarkan Undang-Undang Nomor 6 Tahun 2014 tentang Desa seharusnya lebih diperkuat. Sebab Ketentuan UndangUndang Nomor 6 Tahun 2014 tentang Desa maupun dalam Peraturan Pemerintah Nomor 43 Tahun 2014 tentang Peraturan Pelaksanaan UndangUndang Nomor 6 Tahun 2014 Tentang Desa, sama sekali tidak menjelaskan tentang jenis perkara/perselisihan, mekanisme, bentuk, produk putusan maupun implikasi hukum dari penyelesaian perselisihan kepala desa. Oleh karena itu, ke depan perlu diperjelas secara eksplist baik melalui revisi Undang-Undang Nomor 6 Tahun 2014 tentang Desa atau melalui revisi Peraturan Pemerintah sehingga dapat menjadi panduan yang jelas dalam implementasi di masyarakat desa sekaligus untuk mendayagunakan fungsi kepala desa sebagai penyelesaian perselisihan guna memperluas access to justice dan mengurangi beban peradilan Negara.

\section{Daftar Pustaka:}

\section{Buku:}

Bank Dunia. 2009. Menemukan Titi Keseimbangan : Mepertimbangkan Keadilan Non-Negara Di Indonesia. Jakarta : Justice for The Poor Word Bank - Sub Office.

Gabriel, Maxwell and H. Hayes. 2006. Restorative Justice Developments in the Pacific Region: A Comprehensive Survey. Dalam Contemporary Justice Review, 9 (2), 2006.

Gregory, Leyh. 2011. Pendidikan Hukum dan Kehidupan Publik. Dalam Gregory Leyh, ed., Hermeneutika Hukum : Sejarah, Teori dan Praktek, terjemahan M. Khozim dari judul asli Legal Hermeneutics. Bandung : Nusa Media.

Idrus Abdullah. 2002. "Penyelesaian Sengketa Melalui Mekanisme Pranata Lokal : Studi Kasus Dalam Dimensi Pluralisme Hukum Pada Area Suku 
Sasak Di Lombok Barat". Disertasi Doktor Program Doktor Ilmu Hukum Universitas Indonesia.

Jazim Hamidi. 2011. Hermeneutika Hukum : Sejarah, Filasafat dan Metode Tafsir. Malang : UB Press.

James, P. Spradley and David W. McCurdy, 1987, Conformity and Conflict, Reading in Cultural Antropogy, Little Brown and Company

Liek, Wilarjo. 1990. Realita dan Desiderata. Jogyakarta : Duta Wacana University.

Mahadi. 1991. Uraian Singkat Tentang Hukum Adat Sejak RR- Tahun 1854. Bandung: Alumni.

Made, Sudjana. 2010. Menghidupkan Lembaga Peradilan Adat Bali. Koran TOKOH - Senin, 20 Desember 2010.

Musakkir. 2011. Penerapan Prinsip Keadilan Restoratif terhadap Penyelesaian Perkara Pidana dalam Perspektif Sosiologi Hukum, Pidato Pengukuhan Guru Besar, Fakultas Hukum UNHAS, 12 Juli 2011.

Nader L. Dan HF. Todd (ed.). 1978. The Disputing Process-Law in Ten Societes. New York : Columbia University Press.

Narwoko, J. Dwi dan Bagong Suyanto. 2007. Sosiologi: Teks Pengantar dan Terapan. Jakarta: Kencana Prenada Media Group.

Pat Howley. 2007. Incorporating Custom Law into State Law in Melanesia, (Queensland : International Diploma in Restorative Justice at Queens University.

Saptomo, Ade. 2010. Hukum dan Kearifan Lokal Revitalisasi Hukum Adat Nusantara. Jakarta: Grasindo.

Sugeng, Bambang. 2011. Penanganan Konflik Sosial. Bandung: Pusat Kajian Bencana dan Pengungsi (PUSKASI) STKS..

Sulistiyono, Adi. 2006. Mengembanngkan Paradigma Non-Litigasi di Indonesia. Sebelas Maret University Press: Surakarta

Soekanto, Soerjono. 1986. Kedudukan Kepala Desa Sebagai Hakim Perdamaian. Jakarta : Rajawali.

Tadiar, Alfredo. 1998. Institutonalising Traditional Dispute Resolution the Philippine Experience. Manila : Asia Pacific Organization for Mediation APOM.

Tim HuMa. 2003. Sekilas Mengenai Peradilan Adat (Catatan dari beberapa forum tentangnya)". Makalah sebagai materi penunjang bagi wartawan pada kegiatan Seminar Peradilan Adat pada tanggal 10 Desember 2003. Sanggau Kalimantan Barat.

Tontowi, Jawahir. 2007. Hukum, Kekerasan dan Kearifan Lokal, Penyelesaian Sengketa di Sulawesi Selatan. Pustaka Fahima : Jogyakarta.

Wignjosoebroto, Soetandyo. 2002. Hukum Paradigma, Metode dan Dinamika Masalahnya. Jakarta : ELSAM dan HUMA.

\section{Jurnal:}

Eva Achjani Zulfa. 2010. Keadilan Restoratif dan Revitalisasi Lembaga Adat di Indonesia. Jurnal Kriminologi Indonesia Vol. 6 No. II Agustus 2010 : 182203, hlm., 193-194. 


\section{Internet:}

Abdul Kholik. 2010. "Menggagas Penyelesaian Konflik Berbasis Kearifan Lokal (local wisdom) (Studi pada Mekanisme Peradilan Adat Clan Selupu Lebong, Bengkulu)", http://blog.unsri.ac.id/revolusi-jalanan/artikel-sosialbudaya/diakses 28 Juli 2010.

Joseph Spence, Sr. 2010. Types of Mediators to Select From. Article Source: http://EzineArticles.com/5133589.

\section{Koran:}

I Putu Gelgel. 2011. Peradilan Adat (Agama) Sebagai Resolusi Konflik. Bali Pos, Senin, 06 Oktober 2011. 